\title{
Santa Anna and his Black Eagle: The Origins of Pari Passu?1
}

\author{
Benjamin Chabot \\ Federal Reserve Bank of Chicago \\ Mitu Gulati \\ Duke University - School of Law
}

\begin{abstract}
One of the most debated issues in international finance is the meaning of the pari passu clause in sovereign bonds. The clause is ubiquitous; it is in almost every single foreign-law sovereign bond out there. Yet, almost no one seems to agree on its meaning. One way to cut the Gordian knot is to track down the origins of the clause. Modern lawyers may have simply copied the clause from the documents of their predecessors without understanding its meaning. But surely the people who first drafted the clause knew what it meant. Four enterprising students at Duke Law School may have found the very first sovereign bond to contain a pari passu type provision; General Santa Anna's Black Eagle. This Essay tells the story of that bond and its equal treatment clause.
\end{abstract}

${ }^{1}$ The views expressed are the authors' and do not necessarily reflect the views of the Federal Reserve Bank of Chicago or the Federal Reserve System.

For comments and conversations about this topic, thanks to Al Brophy and Mark Weidemaier. This Essay owes an immense debt to, and builds on, the discovery of the Black Eagle bond by four Duke Law School students in the Fall semester of 2012, Robin Powell, Samantha Cooper, Ariell Friedman, and Elisa Sielski. 


\section{The Contemporary Drama}

Contracts among sophisticated players, students in a basic contract law class are taught, are carefully vetted by the parties and their lawyers and the terms and conditions are understood clearly by everyone. Under such conditions, theory tells us, courts should err on the side of doing what the parties, through the explicit terms of their contracts, say what their deal is. After all, these are sophisticated parties who know what deal is best for them. ${ }^{2}$

What one does not expect to see in the world of sophisticated high finance are contract terms that parties across an entire industry use and have been using for over a hundred years yet neither party seems to understand. One would think, after all, that after repeated use for over a century, contract terms would become better and better understood.

That then brings us to the story of the pari passu clause in sovereign debt instruments. This little clause, generally no more than a couple of lines long and sporting a bit of latin finery, has become perhaps the most controversial and well known clause in international finance, while at the same time also being the least understood. ${ }^{3}$ The clause has been around in sovereign debt bond contracts for almost two centuries, we suspect. Through the 1800s and early 1900s its use gradually increased, but it was still only in a minority of all sovereign bonds. ${ }^{4}$ In the modern era, however, as its understanding has diminished, its popularity has increased. Today, it is ubiquitous; there is almost no sovereign bond that doesn't

\footnotetext{
2 See Alan Schwartz \& Robert E. Scott, Contract Theory and the Limits of Contract Law, 113 YALE L. J. 541 (2003).

3 The modern literature on this clause is too large for us cite to all of the relevant articles. Recent pieces include Joseph Cotterill, Pari Passu and the Litigators of the Lost Clause, 9 CAP. MKTs. L. J. 18 (2013); Anna Gelpern, Contract Hope and Sovereign Redemption, 8 CAP. MKTS. L. J. 132 (2013); W. Mark C. Weidemaier, Sovereign Debt After NML v. Argentina, 8 CAP. MKTS. L. J. 123 (2013). The history of how the battle over this clause evolved is reported in Robert E. Scott \& Mitu Gulati, The Three and a Half Minute Transaction (2013); see also FT Alphaville's series, “The Pari Passu Saga”, available at http://ftalphaville.ft.com/tag/pari-passu-saga/ (last visited February 8, 2014).

${ }^{4}$ W. Mark C. Weidemaier, Robert E. Scott \& Mitu Gulati, Origin Myths, Contracts and the Hunt for Pari Passu, 38 L. \& SOC. INQUIRY 72 (2013).
} 
announce in its first few pages that investors are protected by a pari passu clause. Figure 1, a 2010 issuance by the Republic of Sri Lanka on the London market, provides an illustration. The pari passu clause shows up on the glossy cover page of the prospectus, in the second paragraph - that is, the paragraph after the first one that described the interest rate and maturity of the bond. 


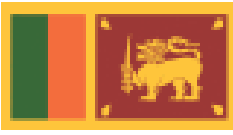

US\$1,000,000,000

The Democratic Socialist Republic of Sri Lanka

$6.25 \%$ Bonds due 2020

The Us51,000,000,000 6.25\% Bonds due 2020 (the "Boeds") of the Covernnent of the Democratic Sodallst

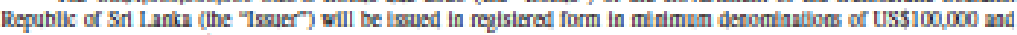
Iniegral multiples of US531,000 in escess thereot. Irierest oa the Bonds will be payable seni-2unully in arrears ou April 4 and October 4 af each year conmenclag on April 4, 2011. The Bonds are not redeenable prior to maturity. Fucepi as deseribed herein, paymenis on the Bonds will be mate without defuction for or of accosat of with by Scl larka. The Bonds will matere at par on October 4, 2020.

The Bonds will coestitule direct, unconditiora, sastbondlinated and ursecured general oblligatioes of the lissuer. The Bonds will at all times rark parl persu anoag themselves in all respects, without any preferenoe of ore over the dher by reason of prionity of daie of issue or dhervise. The Honds vill al all times cank at leas equally with all other present

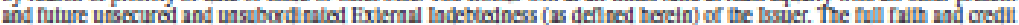
of the Democratic Socialist Republic of Snl Lanka will be pledged for the dee and punctual payment of the principal of, and interest on, the Boads.

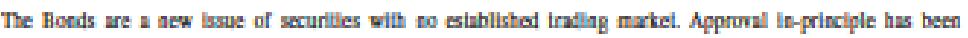
received from the Singapore Finchange Securitles Trading Limitted (the "SCX -ST") for the listing and quotalion of the Boads on the SCXX-ST. The Bonds will be trated on the SCXX-ST I a minimum board lot sine of US5200,000 for 90 long Is the Bonds are lisiad on the SCXX-ST. The SCXX-ST assumes vo resoorsibillty for the comectness of any of the

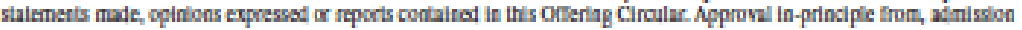

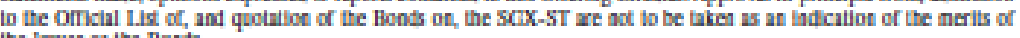
the Isuer or the Bonds.

The Bonds have not been and will not be registered under the US. Sectritles Act of 1933, as amendad (the

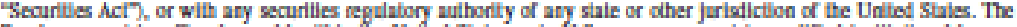
Boads may ad be offered or sold within the Uafied Stales or io U.S. persous, exicept to qualined Irstitutioal buyers

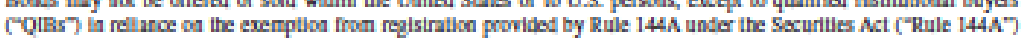

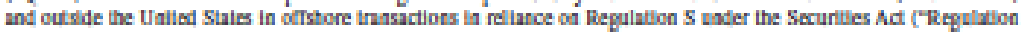
57. Prospective investors are hereby eotined that sellers of the Boeds may be relylag on the eremption from the provisions of Sectioa 5 of the Sectrities Act provided by Rule 144A. For a description of certala restrictioes on resale ir transier, see "Pla of Disiribetion" and "Notice io Investors.

Price: $100 \%$

Delivery of the Bonds is expected to be made on or about Ocinber 4, 2010 through the book-entry facilities of The Depository Trust Company ("DTC").

Joiet Lead Managers and Bookrunaers

BofA Merrill Lynch

HSBC

The Royal Bank of Scotland

Co-Manager

Bank of Ceylon

The date of this Offering Circular is September 27, 2010. 
As best we can tell from the writings of scholars in the area (the academic writing on sovereign bonds contracts is sparse), no one paid attention to this clause for much of its history. That is perhaps understandable because the clause did not seem to make much sense for much of its history, or at least its modern history. The typical formulation of the clause in the early era of the modern sovereign bond market, the mid 1980s and early 1990s, would go something along the following lines:

The bonds will at all times rank pari passu with all other unsecured and unsubordinated External Indebtedness of the Republic.

In some bonds though, the additional word "payment" would creep in to modify the concept of ranking equally. The use of the payment concept has become and increasingly popular formulation of the clause over past decade or so. That additional language often looks something like this:

The bonds will rank equally in right of payment with all of the Republic's other External Indebtedness.

The notion of ranking equally (pari passu is latin for in equal step) is one from bankruptcy. When a company goes bankrupt and its assets are liquidated, the creditors who rank equally get proportional shares. The complication with sovereigns though is that they cannot and do not go bankrupt. They can run out of money, but they cannot be taken over and liquidated by their creditors. After all, their primary asset is the willingness of their citizens to pay taxes, and citizens cannot be seized and then divided proportionally among creditors (at least not in the modern era).

One of us has spent a considerable amount of time asking lawyers in the sovereign debt field why they continue to use a clause that few of them seem to 
understand well. Lawyers provide a range of responses, ranging from "the clause is not completely useless; it protects against a sovereign passing a law that grants priority status to some other creditors over you" to "it is there because it has always been there; no one really thinks about it". 5

As one prominent commentator in the field has written:

[I]t can be said that the pari passu clause mistakenly migrated from secured private lending to unsecured sovereign lending. Once rooted in unsecured sovereign lending instruments it faced provisions like the ones in Spain or the Philippines and become a 'must have' provision in this type of debt instrument. ${ }^{6}$ Then, pari passu clauses stayed in place out of fear of earmarking revenues and the risk that the sovereign preferred one group of creditors over another. These fears, however, were tackled by an expanded negative pledge clause and the Libra and Allied cases. Therefore, if a proper due diligence was conducted there was no need to have a pari passu clause except in exceptional circumstances like the ones in Spain or the Philippines. ${ }^{7}$

The foregoing was perhaps a perfectly good answer until about a decade ago when a case called Elliott v. Peru, was decided by a commercial court in Brussels. ${ }^{8}$ There, Elliott, a U.S. hedge fund, was holding Peruvian sovereign debt that the country was unwilling to pay because Elliott, unlike the majority of other creditors, had refused to restructure its debt. Elliott was instead demanding that it be paid the full contractual obligation. Peru, while stiffing Elliott, was planning to pay its other creditors who had agreed to take write downs and these payments were going to be transferred via Euroclear in Brussels.

\footnotetext{
5 These responses are detailed in Scott \& Gulati, supra note 3. However, the basic flavor of the discussion is also evident in the writings on prominent sovereign debt lawyers. See, e.g., Lachlan Burn, Pari Passu Clauses: English Law After NML v. Argentina, 9 CAP. MKTs. L. J. 2 (2013); Lee C. Buchheit \& Jeremiah Pam, The Pari Passu Clause in Sovereign Debt Instruments, 53 Emory L. J. 913 (2004); Philip Wood, Pari Passu Clauses-What Do They Mean?, 18 BUTTERWORTHS J. OF INT'L BANKING \& FIN. L. 10 (2003)

6 These Spanish and Philippine provisions are ones where domestic law grants, as a default matter, priority to certain debts (for examples, ones that are issued earlier or are registered). The default priority scheme, however, can be unwound or remedied by a pari passu clause in the contract.

7 Rodrigo Olivares-Caminal, To Rank Pari Passu or Not to Rank Pari Passu: That is the Question, 15 L \& Bus. Rev. OF THE AMERICAS 746, 776 (2009).

8 The Brussels litigation is described in Buchheit \& Pam, supra note 5; see also Patrick Wautelet, Vulture Funds, Creditors and Sovereign Debtors: How to Find a Balance, pages 8-9, available at http://orbi.ulg.ac.be/bitstream/2268/87549/1/Vulture $\% 20$ funds $\% 20$ and $\% 20$ sovereign $\% 20$ debtors $\% 20$ Waut elet.pdf (last visited, February 8, 2014).
} 
Elliott then seized upon the pari passu clause to argue to the court in Brussels that (a) it knew precisely what the clause meant and (b) it meant that those funds in Euroclear could not be used to favor one set of creditors (the restructured debt holders) over another (namely Elliott). The Brussels court agreed with Elliot's argument and issued an injunction against Euroclear. Peru did not want to default on its restructured bonds, and settled with Elliott for the full contractual amount. ${ }^{9}$ It was, to put it mildly, a monumental event in the history of sovereign debt because a private creditor has succeeded in using the courts to force a sovereign to pay on its contract obligations.

A discerning reader at this point will probably ask the "how?" question. If the Republic of Peru was refusing to pays its debts to Elliott anyway, who cares whether Elliott has some additional right to proportional payment. After all, the sovereign is refusing to pay, regardless of the rights that the creditor holds. The answer - and this was the magic in the Elliott strategy - was that a pari passu clause is not just a contract tying the debtor and creditor together. Under the Elliott theory, it is one that ties all the creditors together. For one creditor to accept payment (or for an intermediary such as Euroclear to assist in such payment) without the other creditor getting paid proportionally would arguably be an interference with the other creditor's contract rights; thereby giving unpaid creditors potential suits against each other (and intermediaries about to issue payments). Important for purposes of the discussion that follows is that the clause at issue in the Peruvian case had that additional "payment" language modifying the "rank" concept.

Although the Elliott v. Peru was an important case and caused a great deal of drama in international financial policy circles, many in the industry also saw it as an aberration. That, we know now, was wishful thinking. The logic went something like this: "That decision was by an obscure commercial court in Brussels that probably does not even know what a sovereign bond is. No English or New York

\footnotetext{
${ }^{9}$ Wautelet, supra note 8 at p.9.
} 
court (and most foreign issued sovereign bonds today are governed by the laws of one of those two jurisdictions) would ever rule in that fashion." 10

For about a decade that did look to be the case. Various hedge funds tried to reproduce Elliott's strategy against Peru. But they mostly failed, even though there was never any explicit ruling contradicting their articulation of the pari passu clause. Argentina was the biggest target, having performed the biggest sovereign default in history (until then) in late 2001 and then steadfastly refused to pay those creditors who didn't restructure their debts for the deep discounts that Argentina was willing to offer. For a decade, that Argentine litigation seemed to be going nowhere and even the pari passu argument seemed unlikely to work because when it was raised in the early years of the default, in 2004, the US government and the Federal Reserve Bank of New York stepped in to indicate their displeasure and the creditors quickly withdrew that argument. ${ }^{11}$

In November of 2012, everything changed. In December 2011, Elliott had succeeded in getting the trial judge, Thomas Griesa, to rule in favor of them on the pari passu matter; essentially, along the lines of the Brussels court (with a few wrinkles that we will not go into here). ${ }^{12}$ The trial judge's ruling was immediately appealed to the Second Circuit. The assumption of many, if not most, commentators was that the Second Circuit would reverse the trial judge. ${ }^{13}$ However, the Second Circuit Court - historically, the most eminent legal body in the United States when it comes to commercial matters - essentially decided that the clause meant what Elliott said it did (Elliott, in this Argentine case, appeared in a new incarnation, NML Capital). ${ }^{14}$

\footnotetext{
${ }^{10}$ These views are described in Scott \& Gulati, supra note 3; see also Burn, supra note 5 (expressing the view that no English court would follow the pari passu interpretation given by the Second Circuit in the NML v. Argentina litigation).

11 See Anna Gelpern, Sovereign Damage Control, Peterson Institute for International Economics Brief, PB13-12 at p.5 (May 2013).

12 See Gelpern, supra note 11 at 1 (discussing the evolution of the litigation).

$13 \mathrm{Id}$. at 5 (discussing the widespread view regarding a likely reversal of Judge Griesa's December 2011 decision).

14 NML Capital v. Argentina, 699 F.3d 246 (2d Cir. 2012).
} 
Although we still have a bit of the litigation story to tell, part of the reason Elliott won, we suspect, from hearing the questions of the judges, is that it showed up to court with a stronger and clearer argument about what the clause meant. To our reading, it seemed to say that the clause means that if you, the debtor, agree to a pari passu clause (and particularly one with the "payment" language in it) with your creditors, you cannot then later, make preferential payments to some creditors and stiff others. If you want to be able to do that, then don't agree to the pari passu clause. Argentina, by contrast, did not have a particularly strong explanation for what the clause was doing in modern contracts. Although it asserted that it had a clear understanding of clause in the litigation, the Second Circuit was able to easily discern that Argentina's asserted meaning for the clause, one that purportedly drew on industry custom, was far from well accepted and understood in the market. 15 Argentina's strongest argument was to say that no sensible sovereign debtor would agree to a clause that meant what Elliott/NML was asserting it meant (that creditors who have the protection of a pari passu clause have to be paid proportional shares of their claims when a sovereign debtor is unable to pay all their full amount). After all, sovereign debtors in crisis would not be able to pay key creditors, such as the IMF who provides emergency financing in times of crisis in exchange for priority in payments. Argentina's argument found little sympathy with the Second Circuit judges. And perhaps not surprisingly. Courts generally want to be able to assume that contract provisions are drafted by lawyers because they mean something.

In giving Elliott/NML its victory on the pari passu clause interpretation though, the court made clear that it held the drafting lawyers and Argentina responsible for the mess they were in. The Argentine clause had the word "payment" in the second sentence of its pari passu clause and Argentina had also passed something called the Lock Law. ${ }^{16}$ If parties wanted to avoid this kind of litigation, the court seemed to be saying, at least implicitly, they should simply avoid

15699 F.3d at 258.

16699 F.3d at 259. 
using this payment language in their bonds and not pass laws of the type that Argentina had. ${ }^{17}$

Much derision was then heaped upon the Second Circuit's decision by lawyers in the industry, much of it targeting the court's interpretation of the clause. The argument, once again, was that the interpretation saying that the sovereign in default had to pay all its creditors proportionally under a pari passu clause was ludicrous. No sovereign in its right mind would ever agree to such a clause. ${ }^{18}$

Economic theory though tells us that a borrower can be made better off by agreeing to extremely harsh penalties in the event of a failure to perform. ${ }^{19} \mathrm{Such}$ penalties, if enforceable, can change the borrower's payoff in default and serve as a commitment mechanism to help the borrower fulfill its contract. By agreeing to draconian penalties in the event of default a borrower can credibly signal their intent to perform and lower the interest rate that the borrower must pay. One might ask, therefore, whether the pari passu clause is an example of such a bargain.

As of this writing, the Second Circuit's decision is being appealed to the U.S. Supreme Court. And the question as to what the clause means is likely to come up again. We are fairly confident that the Court, if it takes the case, will realize that almost no one in the market really knows what the clause means today. There are various explanations for what it means, but all of those explanations have holes in them. The question then is what should the court do. One option if one takes seriously the story told by many lawyers in the industry that the reason this clause is there is because it simply because it got copied again and again (with words like "payment" being added inadvertently by unknowing associates) over the ages is to

\footnotetext{
17 Cf. Theresa A. Monteleone, A Vulture's Gamble: High Stakes Interpretation of Sovereign Debt Contracts in NML Capital, Ltd. v. Republic of Argentina, 8 CAP. MKTS. L. J. 149 (2013) (suggesting that sovereign issuers react quickly to the case and fix their contracts).

18 See Burn, supra note 5 at 5 ("[o]nly an insane issuer would agree to such a provision"); Buchheit \& Pam, supra note 5 at 883-89 (similar).

19 E.g., Andrei Shleifer, Will the Sovereign Debt Market Survive? 93 Am. Econ. Rev. 85 (2003).
} 
try and track the origins of the clause. ${ }^{20}$ Even if lawyers today are copying the clause by rote, surely the earliest drafters of the clause were not doing that. Someone had to have thought of this clause first. If we could find them, and figure out what they were thinking, then we potentially have a way of cutting the Gordian knot.

That is what the remainder of our Essay does. We believe we have, as a result of a discovery by four Duke Law School students, one the earliest uses of the pari passu concept, if not the earliest. The four students, Robin Powell, Samantha Cooper, Ariell Friedman, and Elisa Sielski, spent countless hours in pursuit of the earliest bond containing a pari passu type clause. A road trip that Robin and Sam made from Durham, North Carolina, to an antique bond auction being held in the basement of some run down hotel in Virginia, in the middle of one of the worst snowstorms of that year, was particularly memorable. They eventually found their clause in a Spanish language bond issued by Mexico in 1843; a bond that was part of consolidation and restructuring of a series of prior Mexican bonds that had been defaulted on during the prior two decades. This 1843 bond was issued roughly three decades prior to what one of us had earlier described as the first use of a pari passu clause in a sovereign bond (Bolivia in 1872). In the remainder of this Essay we lay out the history of this fascinating bond, building on the work of those four superb students.

While we will describe the history of the bond and try to provide as much relevant context as we can, we will stop short of opining on what our findings say for the modern interpretation of the clause. For that, we hope to turn to some of the eminent lawyers who have been arguing about the clause's contemporary meaning and ask them what they make of what we have found.

\section{The Path to the Black Eagle and Equal Treatment}

20 This interpretation strategy is discussed in Stephen J. Choi \& Mitu Gulati, Contract as Statute, 104 MiCH. L. REV. 1129 (2006); cf. Buchheit \& Pam, supra note 5 at 891-917 (engaging in "an exercise in legal paleontology"); Georges Affaki, Revisiting the Pari Passu Clause, in Sovereign Debt Management (Rosa M. Lastra \& Lee Buchheit eds. 2014) (similar). 


\section{a. Mexico during the First Republics: A Remarkably Recalcitrant Sovereign}

The newly independent nation of Mexico successfully listed its first sovereign bond on the London Stock Exchange in 1824. With a war ravaged economy and lack of diplomatic recognition, Mexico was a risky credit, a fact reflected in the $9.14 \%$ yield-to-maturity it had to pay for the 1824 loan. ${ }^{21}$ The loan was well received by the stock market, however, and began trading on the LSE at $69 \%$ of par, a considerable premium above its IPO price of 58 , and reached a high of 83 by February 1825.22 Buoyed by the success of its 1824 issue and formal diplomatic recognition by the United Kingdom, Mexico returned to the London market with another bond offering in 1825 . The 1825 loan had essentially identical terms to the 1824 loan $^{23}$ and was issued with a yield of $6.81 \%$, similar to the yield on United States debt trading in London at the time. ${ }^{24}$

The market's enthusiasm proved misplaced. Mexico defaulted on both issues in October 1827 and over the next sixty-one years bondholders were forced to agree to six restructuring attempts before a final resolution in $1888 . .^{25}$ With each attempted restructuring bondholders accepted haircuts in face value or interest in exchange for promises that this time the Mexican government would pay, only to be

\footnotetext{
${ }^{21}$ For the terms of the loan, see Michael P. Costeloe, Bonds And Bondholders: British Investors And MeXico's ForEIGN DEBT 1824-1888, 12-13 (2003). The 1824 loan had a par value of $£ 3,200,000$, paid a $5 \%$ quarterly coupon in Sterling and had a 30-year term with a sinking fund pledged to redeem $£ 64,000$ in year 1 and $£ 32,000$ plus accrued interest on cancelled bonds in years 2 through 30 . The contract prevented the Mexican government from seeking further loans for twelve months and promised to redeem $25 \%$ of the 1824 loan with any proceeds from future loans. The Mexican government promised to deposit a mortgage bond with the Bank of England pledging the general revenues of the nation and hypothecating 1/3rd of the custom revenues collected at Gulf of Mexico ports as security. The Goldsmidt Banking Company underwrote the bond at an IPO price of 58\% of par which corresponded to a yield-to-maturity of $9.14 \%$.

22 Id. at 16

${ }^{23}$ Costeloe, supra note 21, at 18-20, provides the terms of the 1825 loan. The 1825 loan had a par value of $£ 3,200,000$, paid a $6 \%$ quarterly coupon in Sterling and had a 30-year term with a sinking fund pledged to redeem $£ 32,000$ per year. The Mexican government promised to deposit a mortgage bond with the Bank of England pledging the general revenues of the nation and hypothecating a further $1 / 3$ of all custom revenues as security. Michelena, Barclay \& Co. underwrote the bond at an IPO price of $89.75 \%$ of par, which corresponded to a yield-to-maturity of $6.81 \%$.

${ }^{24}$ Authors' calculations from the London price of U.S. Treasury bonds available at http://eh.net/database/earlyu-s-securities-prices/. Multiple U.S. Treasury bonds trading in London at the time with yields-to-maturity that ranged from $6.23 \%$ to $7.22 \%$.

25 The Mexican government and bondholders agreed to conversions in 1837, 1843, 1846, 1850, 1863 \& 1886.

For details on these conversions, see Thomas Lill, National Debt of Mexico: History and Present Status (1919).
} 
disappointed. ${ }^{26}$ As a result, Mexico found itself unable to list new bonds on the exchanges of the United States and Europe and was forced to rely instead on domestic borrowing to fund its budget deficits throughout the $1830 \mathrm{~s}^{27}$

Much of what would later become known as the "internal debt" of Mexico took the form of short term borrowing, forced loans or mortgages against future revenue streams. Mexico mortgaged future custom revenues by issuing Certificados de Aduanas (certificates that paid interest and were accepted in payment of customs revenue) and forced holders of pre-independence internal debt, merchants, soldiers, pensioners and public employees to extend credit to the sovereign by paying salaries, interest on old internal debt and accounts receivable in pagares, vales de alcane, and vales de amortization (interest bearing promissory notes) which could often be used to purchase government land or pay custom taxes at fixed prices. ${ }^{28}$ In addition to these short term instruments the Mexican government sold assets, farmed taxes, issued bonds backed by the future revenue of the state tobacco monopoly and acquired much needed specie by arranging short-term loans at ruinous rates from local banking houses. ${ }^{29}$

Forced loans and custom certificates were only a temporary solution. Facing threats of internal rebellion and foreign invasion the central government maintained an expensive standing army which drained the treasury and resulted in fiscal deficits that rose from $9.6 \%$ of tax revenues in fiscal year1828/29 to 55\% of

\footnotetext{
26 Details about the payment history of the Mexican debt contracted in London can be found from multiple sources. See, e.g., The Fitch RECord of Government FinAnCES 292-294 (1918); MoOdy's ANALYSES OF InVESTMENTS,

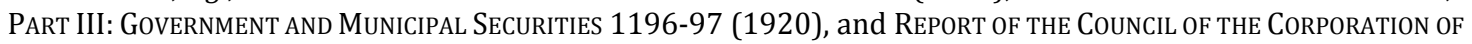
FOREIGN BONDHOLDERS 249-254 (1907).

27 The London exchange was quite strict at that time in refusing to allow sovereigns in default to list. See Mark L. J. Wright, The Pari Passu Clause in Sovereign Bond Contracts: Evolution or Intelligent Design?, 40 Hofstra L. Rev. 103 (2011); Marc Flandreau, Collective Action Clauses Before They Had Airplanes: Bondholder Committees and the London Stock Exchange in the 19th Century, Graduate Institute Working Paper 1/2013, available at http://eh.net/eha/wp-content/uploads/2013/11/Flandreau.pdf. (last visited February 15, 2014).

28 Carlos Marichal, Obstacles to the Development of Capital Markets in Nineteenth-Century Mexico, in How LATIN America Fell Behind: Essays on the Economic Histories of Brazil and Mexico, 1800-1914, at 121 (Stephen Habed ed. 1997); Barbara A. Tenenbaum, The Politics of Penury: Debt and TaXes in Mexico 1821-1856, 58-59 (1986) 29 Details of the Tobacco Debt can be found in David WalKer, Kinship, Business, And Politics: The Martinez Del Rio FAmily in MeXICO, 1824-1867, Chapter 8 (1987). Examples of short term loans at ruinous rates can be found in chapters 1 and 2 of Tenenbaum, supra note 28.
} 
tax revenues by $1833 / 34^{30}$. In November 1834 the government "acknowledged its inability to repay its obligations to speculators and asserted its right to pay some in preference of others." 31

By 1836 the amount of outstanding paper debts accepted at the customs house exceeded expected future custom taxes by such an amount that the market price of Certificados de Aduanas fell to less than $20 \%$ of face value. ${ }^{32}$ Much of this discounted debt was then acquired by Elliott/NML-type distressed debt investors of the day; investment banking houses with the resources and political clout to attempt to collect through either legal action or through the imposition of political pressure via foreign governments.

The Mexican government's next solution to its exploding internal debt was to pass a law on 20 January 1836, which mandated that holders of the custom house certificates convert their certificates into bonds backed by a new fund pledging $15 \%$ of the nation's custom house revenues. With this decree, holders of the various internal debts could no longer pay their customs taxes by presenting their debt instruments at the Mexican customs houses. Instead they had to convert their certificates into the new bonds of the " 15 percent fund" which paid dividends and amortized principal in specie from the 15 percent of custom revenues set aside to service the debt. Although this was effectively a default on the terms of the custom certificates (in the aggregate they were now worth only $15 \%$ of customs revenues rather than $100 \%$ ) the resulting increase in custom collections meant that speculators that acquired Certificados de Aduanas at steep discounts before 1836 profited handsomely from the restructuring. ${ }^{33}$

\footnotetext{
30 Calculations made from Table 8 in Tenenbaum, supra note 28, at 52.

31 Id. at 58.

32 Walker, who examined the archives of one prominent investment bank that specialized in speculation in Mexico's internal debt estimates that most of the internal debt certificates converted into the 15\% fund of 1836 were purchased in the open market for less than $20 \%$ of par value. See Walker, supra note 29 at 166.

33 Id. at 166.
} 
The law of 20 January 1836 created a new cash flow at customs ports which the Mexican government quickly employed as a means of restructuring its external and internal debt. In 1837, Mexico restructured the 1824 and 1825 loans placed in London by offering bondholders a haircut in exchange for a more solid pledge of $16.67 \%$ of the custom revenues. Unlike, the 1824 and 1825 bond contracts that merely pledged custom revenues, the agreement of 1837 changed the facts on the ground by embedding employees of the bondholders' committee in the custom ports and creating the bureaucratic machinery to actually remit payments to bondholders abroad.

With the English debt restructured, Mexico quickly pledged its remaining custom revenues. The Decree of 20 May 1837 created the "17 percent fund" by converting internal debt with a face value of $\$ 2,534,020$ into a $\$ 1,735,030$ tranche with a $0 \%$ coupon and an $\$ 800,000$ senior tranche that paid a $0-4 \%$ monthly dividend from $17 \%$ of the custom revenues collected at the port of Veracruz. ${ }^{34}$ The 17 percent fund bonds traded at $50 \%$ of face value in 1838 but rose to $65 \%$ by January 1839 and $75 \%$ by August 1840 and made, according to one envious account, "a beautiful profit" for the investment houses that purchased the deeply discounted government paper that was eventually exchanged for the 17 percent bonds. ${ }^{35}$

More conversions backed by customs hypothecations soon followed, an 8 per cent fund was established in 1838, a 10 per cent fund in 1839, a new 15 per cent fund to retire the bonds of the original 15 per cent fund in 1839, a new 17 per cent fund in 1840 to retire the bonds of the original 17 per cent fund, a 10\% hypothecation to secure bonds issued to the owners of the tobacco monopoly (tobacco bonds) as compensation for the cancellation of their monopoly contract and finally a 12 per cent fund in $1841 .{ }^{36}$ The various funds plus the $16.67 \%$

\footnotetext{
34 Id. at 167.

35 A note between two partners of the banking house Martinez del Rio Hermanos discusses the profits their competitors made from converting into the 17 per cent fund. See id.

36 Details of these funds can be found in Marichal, supra note 28 at n.7 \& 137-38; Walker, supra note 29 at 166-

67 and Merchant's Magazine and Commercial Review 129 (1844)
} 
previously pledged to the English debt conversion and a 10\% hypothecation to fund the northern army combined to mortgage $98.67 \%$ of Mexican custom revenues which accounted for $55 \%$ of all government revenues in $1840 .{ }^{37}$

The 1837-1841 conversions allowed Mexico to both haircut its internal debt and introduced a new source of specie revenue - the refaccion. A refaccion was a restoration fee charged to bondholders for the privilege of converting their old defaulted debts into an interest paying fund. First introduced during the 1839 conversion when Mexico required holders of $\$ 1,000,000$ of vales de alcance (notes issued in place of government salaries) to pay an up-front $15 \%$ specie fee for the privilege of converting their notes into bonds of the 15 per cent fund. ${ }^{38}$ In 1839 the government also forced the holders of the $17 \%$ fund bonds to pay a $12.5 \%$ refaccion to simply maintain the interest payments on their previously exchanged bonds.

The conversions and refaccions dramatically altered the identity of Mexican internal debt bondholders. In the place of public employees, pensioners and local merchants, banking houses with the cash to pay refaccions and the resources to enforce their contract rights became the largest holders of the post-conversion internal debt. To a modern observer, the speculative behavior of these banks may resemble the legal arbitrage strategies employed by $21^{\text {st }}$ century hedge funds. The investment houses used borrowed money to purchase discounted paper in default and then sought to enforce their contract rights through negotiation and legal maneuvering.

Much of what we know about the collection strategies employed by Mexico's institutional holders of internal debt comes from diplomatic correspondences and a remarkable 1981 Ph.D. dissertation written by David W. Walker chronicling the investment strategies of one of Mexico's largest internal debt holders - the Martinez

\footnotetext{
37 Authors' calculation from data in tables in Merchant's Magazine, supra note 36 at 127-129.

38 Walker, supra note 29 at 166.
} 
del Rio Hermanos. ${ }^{39}$ This family controlled firm was a partnership of Martinez del Rio family members that specialized in distressed debt investing. The partners included family members that held English and French citizenship and were adept at forcing repayment through treaty protections extended to foreign citizens.

\section{b. Martinez Del Rio Hermanos: Distressed Debt Investors of the Era}

Two examples illustrate the strategies of the Martinez del Rio Hermanos. The 1843 decree that created the Black Eagle bond required bondholders of the various custom funds to convert their bonds to Black Eagle bonds at a significant haircut. Martinez del Rio Hermanos converted most of their various bonds but one issue the tobacco bonds - had a pledge of tobacco revenue as security. ${ }^{40}$ The Mexican government had ignored this pledge but the Martinez del Rio Hermanos partners recognized that the tobacco monopoly was one of the few productive assets owned by the Mexican government and likely to be hypothecated in any re-negotiation with the bondholders of the debt listed on the London Stock Exchange. Martinez del Rio Hermanos purchased a majority of the tobacco bonds to establish a blocking position in any future debt negotiation and then sued in the Mexican Supreme court to enforce the pledge of tobacco revenues. ${ }^{41}$ Should the Mexican government attempt to pledge tobacco revenue in a renegotiation of the London debt, Martinez del Rio Hermanos hoped to use their control of the tobacco bonds (to which the tobacco revenue was mortgaged) to force their way to the negotiation table and secure a settlement of internal debt under the protection of the British crown. The plan worked.

The firm prevailed in the Supreme Court of Mexico but the government ignored the ruling and the Supreme Court could not force the sovereign to pay. The Martinez del Rio Hermanos partner with English citizenship used his standing as a

\footnotetext{
${ }^{39}$ Id.

40 The Tobacco bond speculation is described in Chapter 8 of Walker, supra note 29.

41 See Flandreau, supra note 27 (describing the majority requirement for restructurings on the London exchange in the 1800s).
} 
UK subject and the denial of justice in Mexico as a pretense to elevate the dispute to the diplomatic level where the firm's claim was eventually included in the postMexican-American war diplomatic convention that diverted United States indemnity payments owed to Mexico to English bondholders of debts contracted in London and other English citizens harmed by the Mexicans.

The second example involved the Gran Columbia Debt. ${ }^{42}$ In 1826 the Mexican consul in London loaned a portion of the revenues from the English loans to Gran Columbia as bridge financing until the floatation of a Gran Columbian loan on the London Stock Exchange. The anticipated loan never materialized and Mexico was unable to collect on the debt owed it by its southern neighbor. When Gran Columbia spilt into New Granada, Venezuela and Ecuador each new nation assumed a portion of the liability to Mexico. The Martinez del Rio Hermanos managing partners were born in Panama and were citizens of New Granada. Convinced they could use their connections to collect on the debt, Martinez del Rio Hermanos offered to purchase the debt from Mexico in 1839. They were rebuffed due to their low offering price and were unsuccessful with follow-up offers in 1840, 1846 and 1847. Finally, in 1856 , they succeeded in purchasing the debt for roughly $10 \%$ of face value. Two days after acquiring the debt from Mexico, the family used its political connections to hire a New Granada Senator as their agent who promptly secured a settlement from New Granada at a small profit. The Venezuelan and Ecuadorian share of the debt remained uncollected when the Martinez del Rio Hermanos partners were forced into bankruptcy in the 1860s after aligning themselves with the losing side in the Franco-Mexican war. The family paid $\$ 15,000$ to hold onto the debt in bankruptcy. This proved to be a wise choice, as the del Rio heirs managed to eventually use a treaty between the United States and Venezuela to collect $£ 102,000$ in gold from Venezuela in 1902. This windfall, (worth \$13.7 million in 2012 US dollars $)^{43}$ returned the destitute family to prominence. The bonds provided their

42 The Gran Columbian debt speculation is described in Walker, supra note 29, at 208-09 \& 226-27.

43 Authors' calculations from exchange rates and inflation adjustments in the Measuring Worth database http://www.measuringworth.com/index.php 
patriarch with the funds to build mansions in Mexico and educate his children at Oxford. And here is the best part of the return to affluence; the del Rio family hired a French speaking Oxford student named J.R.R. Tolkien to tutor and chaperon the boarding school age Martinez del Rio nephews who were summering in Paris. ${ }^{44}$

The conversions and refaccions of 1837-1841 provided Mexico with much needed revenue and debt relief but concentrated their "internal" debt in the hands of foreign speculators with the wherewithal to enforce payments. For example, the second 17 percent fund (1840) was negotiated between a syndicate of banking houses led by the British firm Montgomery Nicod \& Co. and the Mexican government. The negotiations created new bonds with a $\$ 2,000,000$ par value and a $6 \%$ coupon guaranteed by the hypothecation of $17 \%$ of custom revenues. The bond contract called for the syndicate to pay for the bonds with $\$ 900,000$ in specie and $\$ 1,100,000$ in pagos corrientes (IOUs for unpaid public employee salaries) which were trading at just $12-14 \%$ of par and had "always been of the least value in the Mexican Market.”45 This loan provided the Mexican government with much needed cash but provided their creditors with much stronger contract rights. ${ }^{46}$ When the new 17 percent bonds subsequently went into default, the banks sued under a bond contract clause that stipulated that if default occurred the parties suffering harm could seek damages in the courts. The clause, one of the first acceleration clauses that either of us has seen in any sovereign bond, said that, upon default, investors "shall immediately have the right to claim for losses and damages that would undoubtable occur." 47

\footnotetext{
${ }^{44}$ See Jose Manuel Ferrandez Bru, “Wingless Fluttering”: Some Personal Connections in Tolkien's Formative Years, 8 TOLKIEN STUdies 2, 8-9 (2011).

45 The price of $12 \%$ of par can be found in a letter between the managing partners of the del Rio bank. Walker, supra note 29 at 167; $c f$. Robert Wyllie, Mexico: Report on Its FinanCES Under the SPANish Government, Since ITS INDEPENDENCE 38 (1844) (reporting that the paper was trading at 14\%). The contract terms and the claim that these were the cheapest to deliver bonds in the market can be found in MANUEL PAYNo, MEXICO AND HER FINANCIAL Questions With England, Spain And France: Report by Order of the Supreme Constitutional Government of the MeXiCAn RePublic Appendix II, No. 6 \& p. 71 (1862).

46 Our knowledge of the use of this treaty to enforce the debt contract of the second 17 percent fund comes from Wynne, supra note 29 at n.3 \& p.11; William Wynne, STATE INSOLVENCY AND ForEIGN BONDHOLDERS, SELECTED CASE

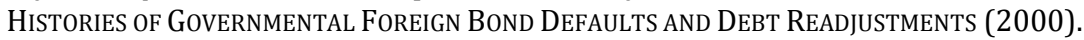

47 Payno, supra note 45 at Appendix II \& p. 70.
} 
In response to the suit, Mexico protested, asserting its sovereign immunity. However, in the eyes of the British government, the acceleration clause mentioned above doubled as a waiver of immunity. According to the British, the Mexican government had waived immunity by agreeing to the acceleration provision in the 17 percent bonds contract. When the Mexican government refused to acknowledge the jurisdiction of its courts in the investors' lawsuit, the banks convinced the British foreign office to intercede on their behalf. The key piece of evidence that was cited to support this view that Mexico had waived its immunity was a treaty between Great Britain and Mexico had signed in 1826, which declared:

The Citizens and Subjects of the Contracting Parties, in the territories of each other, shall receive and enjoy full and perfect protection for their persons and property and shall have free and open access to the Courts of Justice in the said Countries, respectively, for the prosecution and defense of their rights. ${ }^{48}$

The British crown eventually forced Mexico to convert British holders of 17 percent bonds into a new fund backed by both $12 \%$ of custom revenues and the watchful eye of John Bull.

\section{c. Santa Anna and his Equal Treatment Decree}

The historical record tells us that there was good reason for the Mexican government, circa 1843, to want to assure foreign creditors that they would be treated in an equal and fair manner. This was, after all, the era of gunboat diplomacy. From its independence Mexico had sought to use foreign loans as a means to encourage British protection. ${ }^{49}$ In 1838, only five years prior to the issuance of the Black Eagle and its equal treatment decree, France had blockaded

\footnotetext{
48 See Britain And Foreign State Papers XIV, at 621 (1826-27).

49 Take the following excerpt from correspondence between a Mexican representative in London and General Iturbibe on the topic of arranging the first English loan after Mexican independence. It reads, in relevant part: "[I]f the English people have funds in Mexico, I ask you, 'Will not Mexico be given some slight consideration by the government? The re-conquest of Venezuela by the Peninsula would be displeasing to England today because of the $€ 2,000,000$, which she would lose thereby'”. EdGar TurLington, MEXico AND HER Foreign Creditors 21-22 (1930). The renegotiation of 1837 likewise offered British bondholders warrants to land in California and Texas as an incentive to enlist British aid in defending against encroachment by the United States. See p. 212 in Littell The Living Age Vol VII (1846) for the 1837 land warrant contract terms and the section Bondholder's Land Warrants p.81-83 in John Fox Macnamara's Irish Colony and the United States Taking of California in 1846 (2000) for a discussion of Mexico's use of warrants to encourage British protection.
} 
the Mexican coast and attacked its ports to collect on a debt of 600,000 pesos owed its citizens and assure that the Mexican government was to "pledge itself not to throw any obstacles against the rights of the holders of the loan known by the name of 17 per cent loan". ${ }^{50}$ Indeed, General Santa Anna (of the Alamo fame), had lost a leg to the French marines in that bombardment. Nothing, we suspect, focuses a debtor's mind on creditor rights like the loss of a limb in a naval bombardment. Moreover, Mexico probably remembered that British bondholders, who had been treated relatively fairly at the time, vigorously lobbied their government for the diplomatic intervention that eventually lifted the French blockade. 51 The image on the following page is a lovely illustration of the French negotiating their out-of-court settlement with Mexico.

\footnotetext{
50 Yusuf Nzibo, Relations between Great Britain and MeXico, 1820 - 1870, Ph.D. Dissertation, University of Glasgow, Chapter 5, p.5 (1979).

51 "The Committee of South American and Mexican bondholders pointed out to Viscount Palmerston the serious decrease in their trade as a result of this blockade. They pointed out that the claims of the Bondholders in Mexico amount to nearly £10 million, and that their prospects were bound up with British shipping and trade with Mexico. They further pointed out that one-sixth of the customs duties of Mexico went to pay British debts. They pleaded that the suspension of Mexican trade led to the property of the British bondholders to deteriorate to the extent of between $£ 400,000$ and $£ 500,000$. Above all this, the receipt of the annual interest of $€ 250,000$ on the part of their claims, was prevented by the blockade" Nzibo, supra note 50 at 71 ( providing a summary of a letter from John Capel to Viscount Palmerston, Cornhill July 2, 1838, in Parliamentary Papers, Vol. XLVII, 1838, pp. 282-283).
} 
The Prince of Joinville negotiating an out-of-court settlement of the Mexican debt (Veracruz 1838)

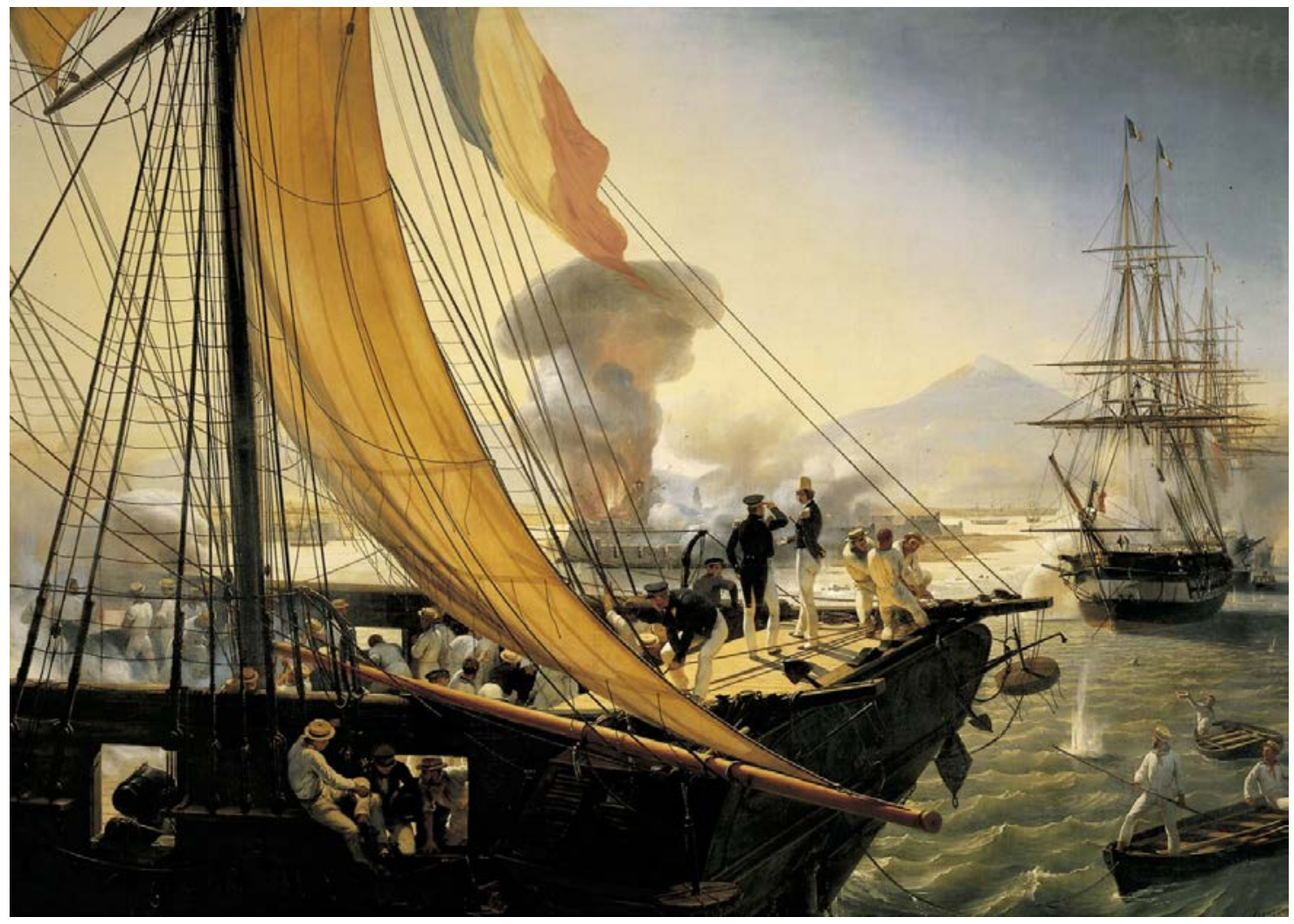




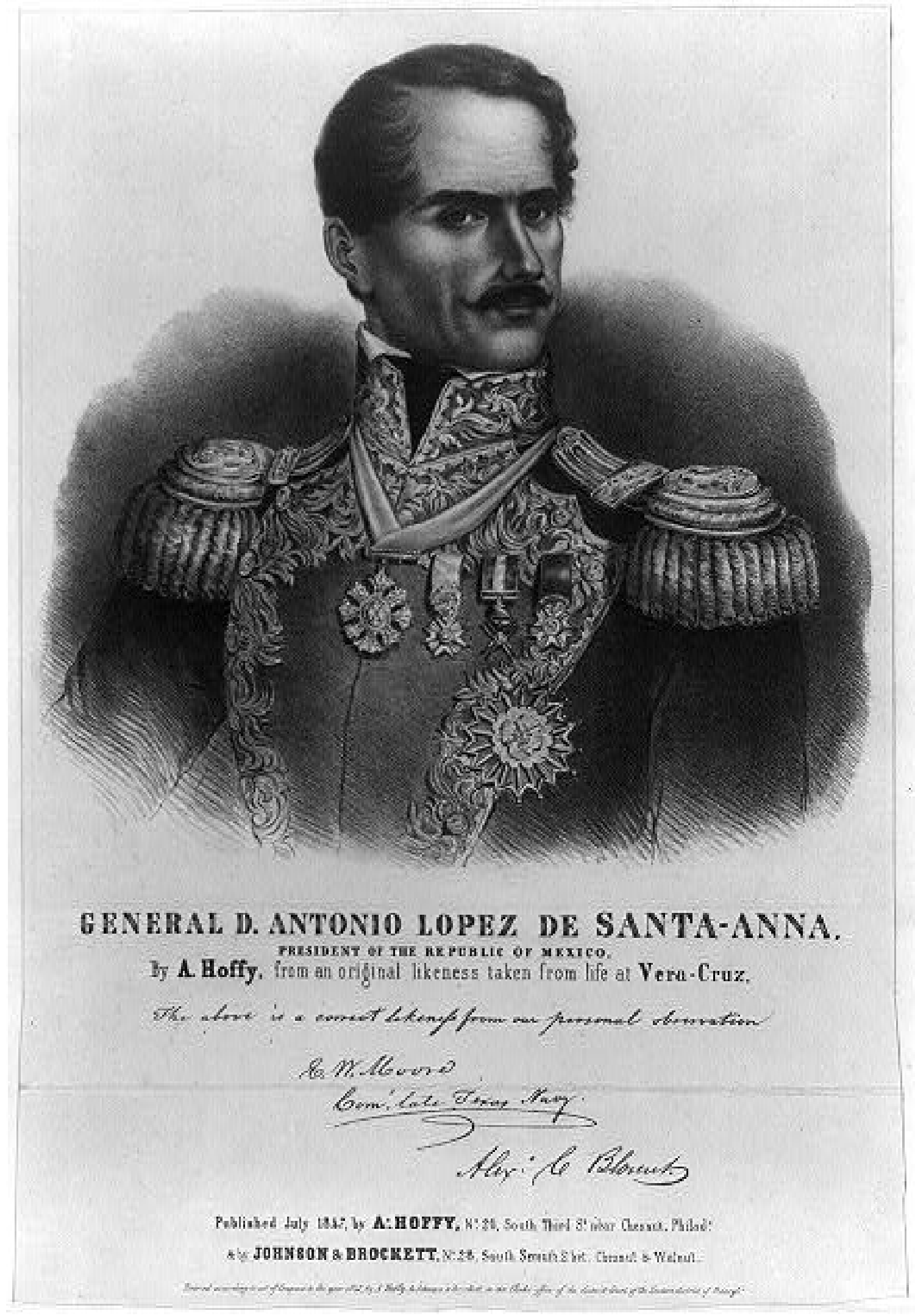


The French blockade of Veracruz diminished Mexico's revenues to such an extent that the government was forced to charge refaccions to the various custom conversion funds and pay the holders of the English debt contracted in London their coupons in custom tax certificates. The value of a custom certificate, therefore, depended upon the location of a bondholder and his personal tax liabilities to Mexico. This unequal treatment of bondholders of equal legal standing was criticized by the London Times for "giving an undue preference to one description of creditor". That same article concluded that "their [Mexico's] credit can never arrive at a satisfactory state in Europe until they have contrived some means of placing all their creditors upon a perfectly equal footing." 52 This unequal treatment was also protested by a major bondholder in a letter to the Chairman of the Committee of Spanish American Bondholders for "putting different bondholders [of the same bond] on an unequal footing." 53

The day after reassuming the Presidency, Santa Anna suspended payments to bondholders of the 8 percent, 10 percent, 12 percent, 15 percent and new 17 percent funds. Four days later the Decree of 14 October 1841 reinstated dividends to these bonds at $50 \%$ of the previous rate in exchange for a refaccions. Bondholders protested but, in the words of the Merchants' Magazine Santa Anna, "withstood the torrent manfully. He was assailed by legations, newspapers and individuals, but nothing could induce him to yield the pressing wants of the government." ${ }^{54}$ The revenues of Mexico were so impaired that a restructuring was inevitable. However, in conducting that restructuring, Santa Anna's administration decided to pay little attention to the formal rights of the bondholders.

\footnotetext{
52 "Money-Market And City Intelligence." Times [London, England] 11 June 1840: 6. The Times Digital Archive. Web. 15 Feb. 2014.

53 See Robert Crichton Wyllie, A Letter to G.R. Robinson, Chairman of the Committee of Spanish American Bondholders (1840), available at http://books.google.com/books?id=wFdDnQEACAAJ\&dq=robert+crichton+wyllie+letter+1840+robinson\&hl=e

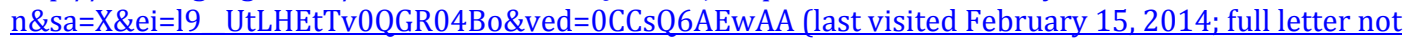
available on google).

54 Merchant's Magazine and Commercial Review 129 (1844).
} 
On February 12, 1842 representatives of the bondholders of the 10 percent, 12 percent, 15 percent funds published a protest denouncing the government's behavior with respect to their contract rights the government itself had established for these funds. ${ }^{55}$ Santa Anna responded a week later with the decree of 19 February 1842 which suspended all payments to the bondholders. The Mexican government abandoned any pretext of equal treatment of the bondholders and over the next five months powerful bondholders worked out side deals for themselves at the expense of their fellow creditors. As Walker explains:

The more powerful native creditors began to make separate deals for themselves. They could bargain efficiently with Santa Anna; family connections, political promises, and appropriate gifts brought favorable resolutions from politicians at the highest levels. The cooperation of the career civil servants who managed routine government affairs was secured through other arrangements. By law, appointees to posts involving fiscal responsibilities had to have afiador guarantee their good behavior in office. Empresarios like the Rubios, the Escandóns, and the Fagoagas put upfianzas (bonds) for dozens of officials, ranging from the head of the customs house in Tampico to the tax administrator of Tlalpam. In contrast to the proven Mexican model, foreign merchants like the Martinez del Rios failed to develop useful relations with either the politicians or the bureaucrats, trusting instead that their legations would look after their interests.

Santa Anna announced in July 1842 that payments to the funds would be resumed under certain conditions. The combined 8 Percent, 10 Percent, 15 Percent, and 17 Percent funds might receive 15 percent of customs duties if each agreed to pay a $\$ 40,000$ refaccion. Because the new quota would not provide enough revenue even to pay interest on the principal owed, the creditors listened to the proposal without enthusiasm. Many of them were shocked to learn three days later of a new decree that lifted the suspension of payments to the 15 Percent Fund. Only after this fund had been paid in full, were the other funds to receive payments from that quota, according to the order of their seniority. The special deal for the 15 Percent Fund was the work of Ignacio Loperena and Antonio Garay, agiotistas who had intimate associations with Santa Anna and had invested heavily in that fund. ${ }^{56}$

55 Walker, supra note 29 at $177 \&$ n.21.

56 Id. at 177. 
With a hostile nation on his northern frontier and memories of French grapeshot fresh in his mind, Santa Anna did not dare alienate Great Britain, so the $16.67 \%$ fund devoted to paying the English debt contracted in London was untouched. Nonetheless, many British citizens held bonds backed by the 8 percent, 10 percent, 12 percent, 15 percent and new 17 percent funds and they appealed to the British crown to intervene and ensure fair treatment.

As a matter of policy the British government tried to avoid interference with the internal loans of foreign nations. When British bondholders of Mexican debt appealed to their government in 1836 to intervene on their behalf the Foreign office replied that the crown viewed internal debt as "private transactions that do not admit the exercise on the part of his Majesty's Government of any official or authoritative interference with a Foreign Government" and when a committee of bondholders asked if the British crown would "raise no objection or place no bar to the bondholders fitting out armed vessels to make reprisals on the Mexican Government" the Foreign Secretary did in fact object in no uncertain terms. ${ }^{57}$

The one action that did stimulate British diplomatic intervention, however, was the unequal treatment of British bondholders vis-à-vis bondholders of equal legal standing. When Santa Anna suspended payments in 1842 to the bonds backed by the 17 percent fund, Martinez del Rio Hermanos appealed to the British consul to intervene noting that "claims of foreign creditors [were] wholly disregarded" while Santa Anna's government made payments to "the Mexican holders of the same bonds and of other paper less formally guaranteed." 58 At first the consul recommended Martinez del Rio Hermanos seek justice in the Mexican Courts but after it became known that Mexican national bondholders had secured payment for

\footnotetext{
57 See Letter \#93, Feb. 24, 1836, in Correspondence Between Great Britain and Communications From the British Government to Claimants, Relative to Loans Made by British Subjects 1823-1847, (hereinafter “Correspondence"). 58 Letter from Martinez del Rio Hermanos to Richard Pakenham, Mexico City, 20 July 1842. Walker, supra note 29 at $178 \&$ n. $26-28$.
} 
their bonds through private refaccions not offered to foreign holders the British minister did seek a diplomatic intervention to press the claims of his nationals. ${ }^{59}$

British diplomatic intervention often carried implicit threats of force that the Mexican government could not afford to ignore. When the Mexican government missed a 1837 coupon payment on the English debt contracted in London the British consul wrote to the Mexicans to express his "disappointment and dissatisfaction" and warned that "a just appreciation of the importance of the subject, and an impartial review of all that has lately passed with regard to it, can hardly now fail to prepare the Government of Mexico for any measures to which the Government of Great Britain may feel obliged to resort, to obtain the satisfaction of a debt." 60 When word reached the British consul in 1842 that the Mexican government planned to change the terms of their contract with the British investors behind the second 17 percent fund he fired off an angry letter warning his Mexican counterpart that while the British government had a desire to "maintain the relations between the countries upon the most amicable and satisfactory footing" he begged the Mexican ambassador to make clear to the President the details of a threatening letter which outlined "the course which this Mission would be compelled to adopt in case the Mexican Government should at any time entertain the intention of setting aside the agreement [with the bondholders]."61 Finally, after a long letter insisting that the Mexican Government honor its contract with the bondholders in the 17 percent fund, the Foreign minister himself, The Earl of Aberdeen, reminded Mexico of “Her Majesty's Government desire to remain on friendly and pacific terms with the Government of Mexico" before reiterating that “Her Majesty's Government confidently expect that the settlement of Mr. Montgomery's [The British Bondholder] claim will meet with no further postponement." 62

\footnotetext{
${ }^{59}$ Id. at 179.

60 Letter \# 98 p. 72, in Correspondence, supra note 57.

61 Letter \#109 p. 79, in Correspondence, supra note 57.

62 Letter \#124 p. 102, in Correspondence, supra note 57.
} 
The British crown's implied threats and appeals on behalf of her bondholders appear to have succeeded. The Mexican government decided to change course and Mexico entered into diplomatic negotiations with Great Britain that resulted in the Pakenham Convention of 1842 which set aside custom revenues for the payment of some British bondholder claims. This convention further stressed Mexican revenue and Santa Anna again defaulted on internal debt with the Decree of 11 May 1843, which converted the bonds backed by revenues from the 8 percent, 10 percent, 12 percent, 15 percent, new 17 percent funds and the tobacco monopoly into an entirely new set of bonds. These were the "Black Eagle" bonds (Santa Anna's nickname was "the Eagle") and were backed by $25 \%$ of custom duties. ${ }^{63}$ Santa Anna notably did not impair any bonds covered by previous English diplomatic interventions. Our conjecture is that the recent British complaints of unequal treatment caused him to include, as part of the preamble to the Black Eagle, language from a decree of 11 May, 1843 that pledged equal treatment to all bondholders. The decree, that is reproduced in Appendix I, along with the front and back pages of the Black Eagle bond, said, in relevant part, that its intention was:

[T]o establish among the creditors just equality, as much as regards the rate of interest as in the order of payment

-Decree of $11^{\text {th }}$ May $1854 .{ }^{64}$

Why did Mexico insert equal payment language into the May $11^{\text {th }}$ decree and the Black Eagle bond? One possibility is that the commitment to equal payment was an attempt to forestall British intervention on behalf of her bondholders. In a letter dated May $9^{\text {th }}$, just two days before the decree that created the Black Eagle bond, the British ambassador in Mexico notified his Mexican counterpart that British bondholders had complained that "bills have been received in Mexico in favour of other parties interested in various appropriations of portions of the custom revenue... while no bills have arrived to their orders for the 8 per cent belonging to

63 See Ann F. Crawford, The Eagle: The Autobiography of Santa Anna (1988).

64 Payno, supra note 45 at Appendix No. 11 \& p. 79. 
them [the British Bondholders]."65 The letter went on to warn the Mexicans that "this direct breach ... leaves no other option to the Undersigned [The British Ambassador] than to act in accordance with those instructions, the tenor of which has been already communicated to his Excellency by Mr. Pakenham's note of the $22^{\text {nd }}$ of December last, and confidential letter of the $19^{\text {th }}$ of January following" and reminded the Mexican government about a previous letter "pointing out the consequences that must necessarily ensue from setting aside the arrangement with [the British bondholders]." 66 The referenced letters are not included in the Parliamentary Papers but from the tenor of the British Ambassador's letter and the Mexican response we assume that they likely outlined the extra-legal actions that might be taken should British bondholders' interests be ignored.

British bondholders' interests could not be ignored. Upon receiving the May $9^{\text {th }}$ letter, the Mexican government immediately promised to give British bondholders their day in court and issued the Decree of 11 May which created the Black Eagle bonds. ${ }^{67}$ Mexican diplomats thereafter cited the Decree's equal payment promise as one of the reasons the British crown should refuse her bondholders pleads to intercede. 68

Some British bondholders refused to convert their bonds into the new Black Eagle bonds and enlisted the British Ambassador to protest. On August 16 $6^{\text {th }}, 1843$ the acting British Ambassador, Percy Doyle, sent a threatening letter that expressed, "in an imperious and threatening tone" 69 terms which, in the opinion of the Mexican Ambassador to the United Kingdom, "ought to have powerfully struck its [the

\footnotetext{
65 Letter \#112 p. 81-84 , in Correspondence, supra note 57.

66 Id.

67 "May 9, Mr Doyle [British Ambassador], following a new representation by Messrs Montgomery, addressed another note to the government, complaining of the fact that no bill had been delivered by the customs office in favor of these Messrs following the instructions of March 1, although other individuals with interests in the customs revenues had received them [bills]. Upon receiving this note, the [Mexican] government resolved to send this affair back to the courts. While waiting, by a decree of May 11, it assigned one-fourth of the product of all the maritime customs, as a common fund for the payment of Mexico's domestic debt. Letter \#123 p. 94-99, in Correspondence, supra note 57.

$68 \mathrm{Id}$.

69 Letter \#116 p. 87-89, in Correspondence, supra note 57.
} 
Mexican Government] attention."70 The Mexican government responded with a letter outlining their reasons for default and argued that the British crown should not intervene. Mexico's arguments in 1843 should look familiar to anyone well versed in contemporary sovereign debt negotiations. In addition to arguing that the debt should be renegotiated because Mexico was broke and its debt imposed "a most monstrous prejudice (lesion enormisima) ${ }^{*}$ to the interests of the exchequer - a condition that makes [the bonds] void", Mexico argued that the British holdout bondholders were actually requesting special treatment by expecting to be paid according to their contracts rather than accepting the exchange into the new Black Eagle bonds like everyone else. In the words of the Mexican Finance Minister, "in this course of conduct [Mexico's default and restructuring], which has been followed by all nations when they have arrived at a similar crisis, the creditors of the State remarked the good faith of the Mexican Government and acquiesced [to the exchange], with the exception of Messrs. Montgomery, Nicod and Co. [the holdout bondholders] and some few others led away by their example, in a measure which secured their interests, and reduced them to an equality, as justice required."71

In a follow-up letter dated Oct. 14, 1843 the Mexican ambassador to the United Kingdom noted that the holdouts stood to make huge profits from their purchase of defaulted bonds "at a low price on the spot from the poor widow and starving invalid" and had suffered no more than other creditors. ${ }^{72}$ The Mexicans argued that since the May $11^{\text {th }}$ decree offered "to all creditors" the same exchange into Black Eagle bonds, British subjects did not suffer unfair treatment and the British government should agree with the Mexican view that the bonds "proper and natural character, to wit, that of a private contract between individuals and a government" and should not warrant British intervention. ${ }^{73}$ The British Foreign Secretary, the Earl of Aberdeen, responded with a letter dated Nov.1, 1843 that (before closing with the threat that he desired their countries to remain on "pacific"

70 Letter \#123 p. 94-99, in Correspondence, supra note 57.

71 Letter \#116 p. 87-89, in Correspondence, supra note 57.

72 Letter \#123 p. 94-99, in Correspondence, supra note 57.

73 Letter \#123 p. 94-99 , in Correspondence, supra note 57. 
terms) disagreed with the notion that the United Kingdom should not intervene because the British holdout bondholders were treated equally by the May $11^{\text {th }}$ exchange offer. ${ }^{74}$

\section{What Does This Mean Today?}

As promised at the outset, we are not going to opine as to what our findings mean for the contemporary interpretation of the standard pari passu clause. Instead, we note four observations that can hopefully be useful starting points for a discussion of the relevance of the history to the interpretation of the modern pari passu clause. The hard work of connecting the historical story to the contemporary interpretation, however, is one we leave to the real experts.

\section{a. When Did the Concept Originate?}

Most contemporary commentators (including one of us in prior work) locate the origins of the pari passu concept in the issuance of sovereign bonds secured by pledges of revenues in roughly the period ranging between 1870-1930.75 Further, when it comes to the use of the "payment" language to modify the rank concept, commentators seem to believe that that crept in long after the "rank" concept was well established (perhaps as late as the1980s). The language from Santa Anna's decree that is reproduced on the Black Eagle suggests that the pari passu concept, in its payment incarnation, originated at least four decades prior to what the literature suggests.

\section{b. Where did the Concept Originate?}

As noted earlier, there are a variety of stories that are told regarding the origins of pari passu, including ones about gunboats, earmarks and domestics laws

\footnotetext{
${ }^{74}$ Letter \#124 p. 99-103 , in Correspondence, supra note 57.

75 For an articulation of the various views, see Weidemaier et al., supra note 4 at 77-81.
} 
producing involuntary subordinations. Our story locates the origins of the concept in fears that the gunboats would be sent in to engage in a little extra judicial enforcement (and not in creditor fears of future grants of preferences and involuntary subordination via local laws about timing of the issuance and the sort). Perhaps under the international law of the time, unequal treatment of creditors was considered adequate justification for the gunboats to be sent in?

\section{c. A Decree; Not a Contract Clause}

Much though we would like to assert that the equal treatment language of the Black Eagle is the first example of the pari passu concept showing up in contract clause, that language is from the Presidential decree and not a contract provision. (Although the key language of the decree is then reproduced prominently in the bond.) Why did Santa Anna promise equal treatment via a decree rather than in the contract provisions? Was that because he thought that his promise would be stronger if it was made via a decree or was it because it was weaker? We do not know. It still remains the case though that the first time we see the pari passu concept show up in a contract provision in a sovereign bond is in 1872 for Bolivia.

\section{d. Translating a Concept From an Era Without Legal Enforcement}

If one concludes (a) that the pari passu concept is indeed one that has existed for centuries in sovereign bonds and (b) that this history might be able to illuminate how we understand the clause, there is still one large leap that needs to be made. That is that the origins of the clause seem to lie in a period when there was no real possibility of legal enforcement. The clause had value, we suspect, because its violation provided a justification for the gunboats to be sent in. Today, there are no gunboats that will enforce debt contracts, but there are courts that will at least try. Question is: How does this old clause, devised for an entirely different era, get translated into the modern era. 


\section{Appendix:}

Official Translation of the May $11^{\text {th }}$ decree (Payno 1862) and Black Eagle Bond

Decree of 11, May 1843:

\section{12}

Decree of the 11th of May 1843.-Orders the geparation of 25 per Cent of the import dues in ald the Maritime Cugtom-Hougeg, ex-

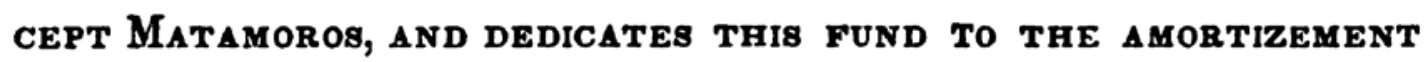
OF THE PUBLIC DEBT.

Department of Finarce.-Section 1st.-His Excellency the President ad interim has been pleased to issue the following decree:

Antonio Iopez de Santa-Anns, Benemerito of the nation, General of Division, and President ad interim of the Mexican Republic, to the inhabitants thereof, Know Ye:

That the present situation of the Exchequer requiring the most equitable, regular and ceonomical distribution of its funds, as well to provido for the indis. 
pensable expenditure of public administration, (upon which depends the preservation of society, which could not exist without the just recompense due to its officers), as to satisfy and guarantee the debt which by the orders in circulation is incumbent upon the maritime and inland Custom-Houses, the tax-offices and other public departments,-in which are compromised the national interest and credit:-it being evident on the other hand that this last important object would never be attained without ensuring the first in a permanent and certain manner, as on the contrary the necessity would frequently occur of disposing of the funds assigned thereto: desiring to place the seal of inviolability on the sacred deposit of the assignments made for the payment of the debt mentioned, confiding the same to the intervention of the parties interested therein, and severely prohibiting the agents of the Government from touching the same: wishing, in conclusion, to establish a just equality amongst the creditors, as much as regards the rate of interest as the order of payment, by which the large sums comprised in the debt, which are now out of circulation, will be put into movement: in virtue of the power conceded to me by the 7th of the bases adopted in Tacubays and sanctioned by the nation. I have deemed fit to decree as follows.

Article 1st. Fron the publication of the present decree, a Fund shall be formed from the Twenty five per cent. of the whole of the import duties in all the Maritime Custom<Houses, except Matamoros, which Fund shall be solely and exclusively dedicated to the payment of interest and redemption of the capitals at present bearing upon the public offices, in which all payments assigned to them shall at once cease excepting only the expenses of administration.-The part destined to the redemption of the English debt, and that fixed by the Convention of the 15th October last, shall continue to be separated and distributed in the terms already stipulated.

Article 2nd. This Fund shall be inviolable, and from no motive or circumstance whatever, shall it be applied' to any other object, under the irremissible penalty of loss of employ to any functionary who should contravene the present orders.

Article 3rd. The present Decree is considered to embrace the following liabilities.

First. - The Bonds of the various Funds of Eight, Ten, Twelve, Fifteen and Seventeen per cent.

Second.-Those of the Eight per cent lately issued.

Third.-The Balance that may be still due of the debt contracted by the Government with the late Tobacco Company, at the time of receiving that negotiation.

Fourth.-All the orders in circulation against the maritime and inland Custom-Houses, and Tax Offices as well as against the other revenues and funds of the Exchequer, without any exception, whatever might be its origin, either by direct or indirect payment or by way of compensation, the assignment made for the amortizement of copper money remaining without alteration of any kind.

Article 4th.-The General Treasury of the nation, shall, within the precise term of two months, adjust the debt mentioned, cspitalixing the interests that 
may have been expressly stipulated, and which may be due up to the end of the present month, so that the whole amount thereof, without any distinction, may bear from the,1st day of June 6 per cent. interest per annum. These adjustments shall be passed to the Department of Finance for their proper examination, qualification and approval, after which time no credits of the classes named shall be admitted or reputed as amongst those recognized by the Public Exchequer.

Article 5th.-In order that those creditors who may not have contributed to the additional subsidy ("refaccion") of 6 per cent, dictated by the 2 nd article of the Decree of the 26th December, may partake of the benefits offered by the present decree, they shall effect the same in three payments, to be made in cash to the Treasury General at twenty, forty and sixty days from the present date. Those who should not conform to the "refaccion," shall be paid after the whole of the creditors complying therewith shall have been satisfied, and the interest on their credits, when entitled thereto, shall be reduced to 6 per cent. per annum.

Article 6. The Treasury General shall fix a prudent term for the presentation of the documents justifying the credits mentioned in Article 3, and after immediately cancelling the same, shall issue other new doeuments in their place, to be denominated "Bonds of the Debt against Public Offices" divided in such fractional parts as may suit the persons interested and with all the necessary precautions, under the strict responsibility of the Treasurers, that the first named Bonds may not again be put in circulation, and to prevent the falsification of the second, after their being cancelled as ordered in Article 4.

Article 7. Within fifteen days from the clearance of the cargoes, the Maritime Custom Houses, shall remit to the Treasury the Twenty five per Cent mentioned, in bills against the persons owing the import duties, previously guaranteed, and drawn in favor of the Agent named by the parties interested in this Fund which shall be immediately delivered to the principal Agent, ("propietario apoderado") who shall recover said bills, and at the conclusion of the term of two months as designated in Article 11, shall commence to make the quarterly payments for interest, and successively and proportionately for the redemption of the capitals.

Article 8. The Bondholders of the debt referred to against Public Offices, shall name a Board of Directors to watch over the proper observance of this law, and to promote every thing that may be conducive to its strict fulfilment; and the Government binds itself to impart to said Board every protection.

Article 9. The Gorernment shall not enter into any contract pledging the free part of the Customs, or the other revenues of the Exchequer; and in the extreme case of doing so, shall communicate the same to the Board of Directors of this Fund, and to all those who it is believed may make them proposals, so that preference may be given to such as maj be most advantageons to the public interests.

Article 10. The nett products of all the revenues shall be delivered to the General and Departmentsl Treasuries, in order that the proper distribution may be made thereof in exact conformity with the laws. 
Wherefore, I order the present to be printed, published and circulated, and that due fulfilment be given hereunto.

National Palace al Tacubaya, this 11th of May 1843.-Antenio Lopex de Santa-Anna.-Ignacio Trigueras, \& Minister of Finance."-

And I. communicate the same to your for you information and the corresponding purposes.

God \& Liberty. Mexico, May 11th 1848.-Trigueros.

Note printing error in date (it should be 1843 NOT 1848)

Black Eagle Bond:

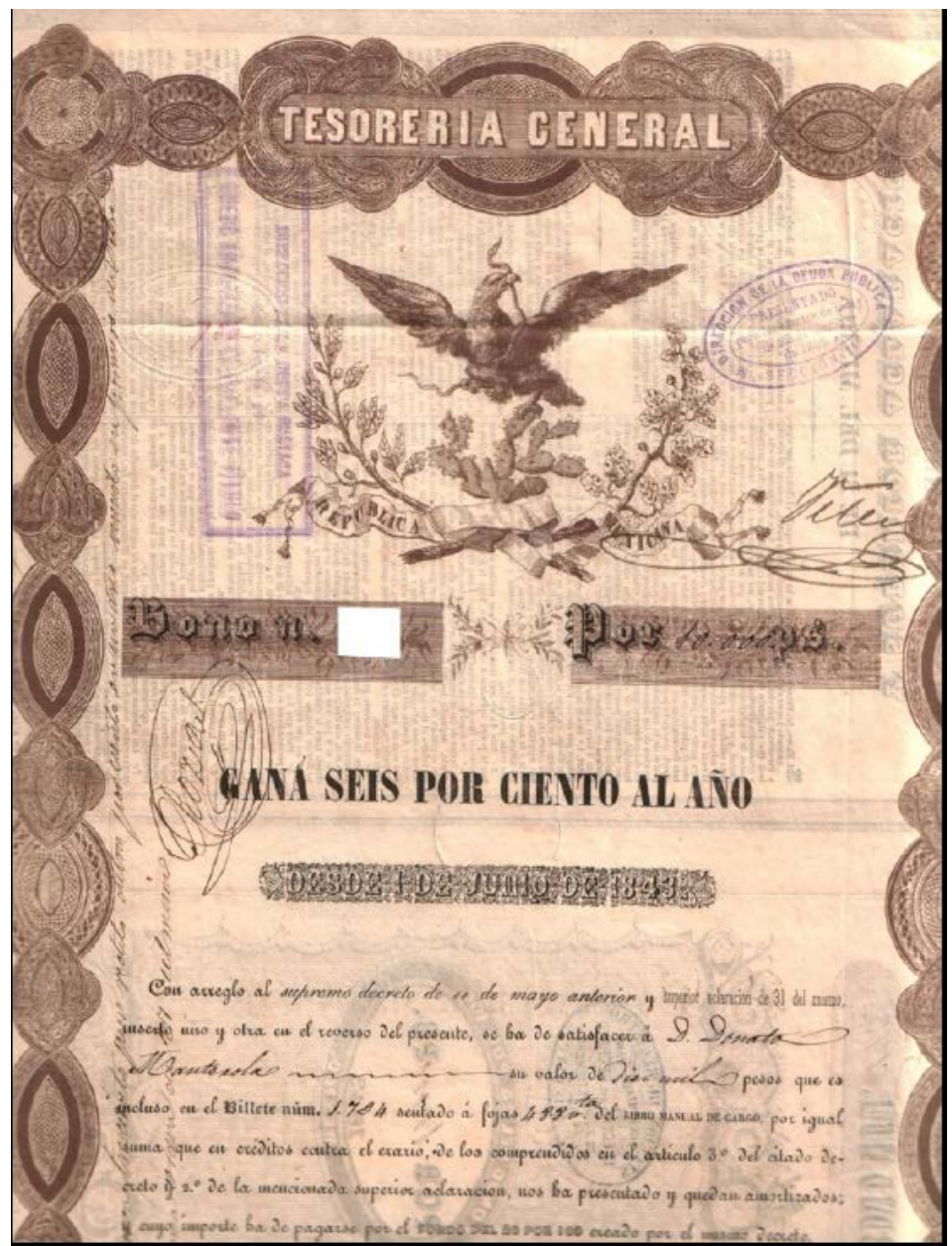




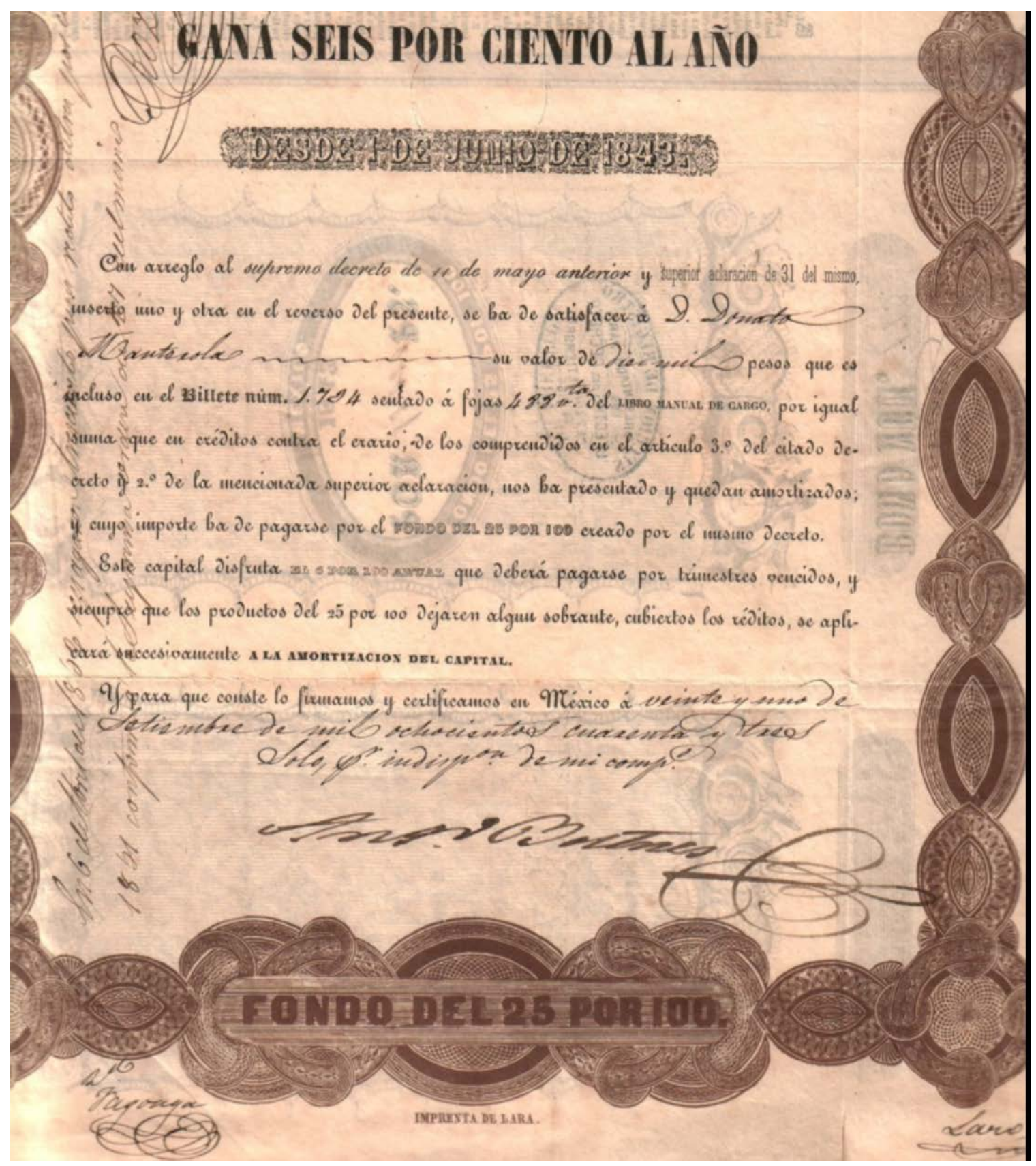

